\title{
SONIC CITY
}

An Exhibition of Photography, A/V installation, community action

by

Philip Skoczkowski

B.A. (Hons) New Media 2014

B.A. (Hons) International Development Studies 2014

University of Toronto

A MRP presented to Ryerson University

In partial fulfillment of the requirements of the degree of

Master of Fine Arts

in the Program of

Documentary Media.

Rally Gallery 12 Ossington, June 2nd

Toronto, Ontario, Canada, 2016

MRP 2016

(CPhilip Skoczkowski 


\section{AUTHOR'S DECLARATION FOR ELECTRONIC SUBMISSION OF A MRP}

I hereby declare that I am the sole author of this MRP. This is a true copy of the MRP, including any required final revisions.

I authorize Ryerson University to lend this MRP to other institutions or individuals for the purpose of scholarly research.

I further authorize Ryerson University to reproduce this MRP by photocopying or by other means, in total or in part, at the request of other institutions or individuals for the purpose of scholarly research.

I understand that my MRP may be made electronically available to the public. 


\begin{abstract}
:
By taking participatory action research, utilizing sound as a means of harnessing the socio-cultural, and documentary exhibiting as mimesis, this paper takes themes of contemporary underground dance music culture, sonics, political engagement, and human development in urban spaces and looks at the key processes involved in formulating my documentary project Sonic City throughout the years 2014-2016. From personal experiences in Berlin (GER), London (UK), and Toronto (CAN) to research on the ephemeral nature of what creates thriving underground dance music scenes, this paper proposes that discotheques are vital and underestimated spaces for urban development, where complex sociocultural monads of production and consumption are exercised and actualized. Sonic City as a documentary project is meant to shed light onto the places, spaces, and people involved in this vibrant culture, while as an artistic endeavour is attempting to put relational aesthetics at the forefront of documentary exhibiting, blurring the lines between gallery expectations and dance space experience.
\end{abstract}

\title{
ACKNOWLEDGEMENTS:
}

First and foremost my greatest thanks goes to my mother Joanna for her relentless support and being the best mum possible. I would like to express my very great appreciation to my supervisors Katy McCormick and Don Snyder for the time and energy they have spent handling me. I would like to offer my special thanks to Professors Edward Slopek and Steve Goodman for guidance in the abstract and confidence in the obscure. I would also like to thank the classes of 2015 and 2016 of the Documentary Media program at Ryerson for enduring the chaos I would bring to the table.

My special thanks are extended to the staff of Ryerson University Image Arts building as well as collectives and individuals that have hosted me and supported: ItsNotUltsMe, Hyperdub, Swamp81, Boiler Room, West Norwood Cassette Library, Modern Ruin Records, Jim Warboy, and Elaine Tam.

\section{DEDICATION:}

We are one. 


\section{TABLE OF CONTENTS:}

Chapter I:

Introduction. .pg1

Synopsis:

Background:

Scope:

Project intent:

Chapter II: Literature review/ context/ experience .pg6

Energy harnessing sites:

Contemporary human spaces of engagement | BAR 25

Place / Space:

Music reflective of human condition:

Chapter III: Methodology.

I-Travel:

Finding subjects:

Large format photography:

Field recordings | Mixing techniques:

On the ground research.

Appropriating international development models into documentary practice:

Virtual reality + real life integration.

Hosting events for community with community:

Integrating social media with documentary exposure:

http://notyourcommonfolk.tumblr.com :

http://spacexlife.tumblr.com :

Chapter IV: Documentary Relevance.

Influences:

Real world springboard platform:

Conclusions: pg46

Glossary pg48

Table of Appendices: pg50

Works Cited: pg53 


\section{Chapter I: Introduction.}

This documentary is about investigating spaces, places, and people that are at the core of an invaluable form of culture: that of music and knowledge, rhythm and dance. The project can be framed as "a photographer's inquiry" into underground dance music culture, where the goal is to depict the essence of a recently-developing phenomenon growing within music culture, which takes presence in hyper reality and physical spaces, where on one hand there are unprecedented freedoms in communications enabling social organization, while on the other hand restrictions exist that undermine communities and access to capacity-enhancing music venues. The project aims to delve deeper into dance music culture and go beyond often-misconceived notions of what dance clubs or discotheques really are: physical spaces which get actualized into places of complex and direct socio-cultural discourse, where sociological rhythmic analysis takes place and ripples into the consciousness of participants and everyone involved (this means everyone involved in making the "vibe" happen: venue owners, staff, engineers, djs, producers, promoters, etc.)

\section{Synopsis:}

Spaces and places are where people organize themselves, where the human condition is lived out, where both group and individual identity are shaped. Contemporary urban environments dictate the way we organize ourselves, the 
way we live out our identities and exchange social capital between one another.

Given that we have sonic bodies, bodies whose fundamental mode of perception is through its entire apparatus (the body), we are able to bring fictional ideas into real life through spaces designated for sonic dominance and audio/visual stimulation. These spaces go beyond the idea of club or bar; these are sonic spaces which are today's future of progressive socio-cultural exchange and which channel harnessed energy into fostering human development.

\section{Background:}

The project explores the relationship between urban development and music culture. A photo-based, multimedia story that revolves around the lives of music producers, djs, mcs, dancers, spaces and places-(NYCF [\#NotYourCommonFolk] is how l've been hashtagging this project to create and propel content online) are the people putting their sweat, tears, and blood into musicking ${ }^{1}$ on highly contested urban soil.

Though largely inspired by German squatters in the 80 s and 90 s and their relentless occupation of post-divided Berlin as a means of creating their own

\footnotetext{
1 The essence of music lies not in musical works but in taking part in performance, in social action. Music is thus not so much a noun as a verb, 'to music'. To music is to take part in any capacity in a musical performance, and the meaning of musicking lies in the relationships that are established between the participants by the performance. Musicking is part of that iconic, gestural process of giving and receiving information about relationships which unites the living world, and it is in fact a ritual by means of which the participants not only learn about, but directly experience, their concepts of how they relate, and how they ought to relate, to other human beings and to the rest of the world. These ideal relationships are often extremely complex, too complex to be articulated in words, but they are articulated effortlessly by the musical performance, enabling the participants to explore, affirm and celebrate them. Musicking is thus as central in importance to our humanness as is taking part in speech acts, and all normally endowed human beings are born capable of gestures but of making their own. (Small, Christopher. Musicking: The Meanings of Performing and Listening. Hanover: U of New England, 1998.)
} 
culture, music movements have always been intrinsically tied to physical spaces and places people's individuality and expression. The notion of music playing a vital role in urban development is not new, nor can it be easily dismissed, considering its profound implications. These ranging from the early days when jazz would be played for white folk during "club" hours—dictated to suit the rich and powerful-only to unveil its true potential after hours, when AfricanAmericans would spurt out dancing; to the formation of disco in New York's Lower East Side (discotheque deriving from French, meaning phonographic collection aka phonographic bibliotheque, which began in the 40 s and 50 s and played an important role for socio-political gatherings during the time when live bands were prohibited to perform); to the development of house and techno music (in Chicago and Detroit) alongside genres such as reggae and dancehall (in Jamaica, the, UK and quickly worldwide) which would end up influencing one another as much as any chefs table fusion cuisine from around the world.

\section{Scope:}

This project is focused on, but not limited to, contemporary music pushers: producers, djs, promoters, hosts, personalities, club owners, local council government officials, and activists. The subject at hand, though physically revolving around spaces, people and machinery, is difficult to put a finger on as it is more of processes rather than mere objects. The idea of music as a profound socio-cultural rhizome-ever evolving, delicate yet powerful, ephemeral yet everlasting, present here and there, in combination with actual spaces alongside 
the people occupying them-is what the documentary is attempting to grasp and convey. Through the actualization of sound system culture, djing, MCing, and seemingly rhythmic analysis of such meditated experiences this project aims to explore the timelessness of sonic vibrations utilization as social gluing devices in context of the cultural capacity building value of community experience vital in urban development. In order to get a glimpse into these spaces and places, bass-heavy dance music within Toronto (CAN) / London (UK) is what is primarily under investigation in relation to hyperspace/ online communication. The notion that private, public, and government entities are lacking communication is considered in shaping the narrative. This has been derived from first-hand experiences-there is a serious problem of appropriating sound systems in music spaces in the city, from venue owners not caring about sound, to zoning laws preventing spaces to be sonically liberated. Interviews with people bring out noticeable realities of underappreciating proper sonics and a general trend of having "clubs" as merely spaces for intoxication via consumerism rather than of community gathering, experiences and discourse.

Using Julian Henriques Sonic Bodies, as recommended by Professor Steve Goodman (aka Kode9) during a conversation in London, the construction of this documentary is based on Henriques's findings on Jamaican soundsystem culture and comprises the corporeal (frequency), the mechanism (amplitude) and material (medium), a trifecta which creates the sociocultural (periodic movement) or human timbre in music terms (Henriques, 2011: 61). The intention is to take the idea of mixing records (but not exclusively) by people within spaces supplied 
with well- tuned powerful sound systems and translate some of the complex behaviors and outcomes that go along with such acts into an exhibition/ event that uses visual installation to accompany the sonics being output by the subjects themselves. I am attempting to layer non-linear narratives by exhibiting the work I've been producing and literally giving a voice to some of the subjects in the project by having them perform sonics within the exhibition space. My role as a documentarian goes beyond mere pointing and shooting and delves into the role of a socio-cultural sonic curator. From careful sonic selection, to appropriate space utilization and peoples occupation of it: I am attempting to utilize audio/visual installation outside of the typical gallery and into the gray areas where much of this music thrives in fundamentally. On one hand I am trying to mimic certain temporal sonic spaces, while on the other I am trying to make the images, video clips, and sonics relate to one another while addressing the rhizomatic nature and importance of music culture as a vital urban development driving device.

\section{Project intent:}

First and foremost this project has aimed at observing and trying to understand relationships between notions of contemporary human development and music culture with a focus on bass-heavy dance music. It uses music culture as a platform for inquiring about social capital organization: how music is produced, disseminated, and distributed; and its actualization into, and reflection of, complex socio-political-cultural-economic webs of contemporary human 
conditions. By recognizing music cultural pockets around the world, and their inter-independence, the underlying intention of this project has been to learn about the complex relationships between people, places, spaces, and in many ways how the living and breathing organism of the so-called music underground works.

To start off with the idea of physical spaces in urban environments, which are crucial in contemporary social engagement this project uses music culture as a platform to inquire about how these factors play out vis-a-vis urban development. Since activating this project in February 2015, the intent in this work was to integrate social capital building devices (engaging people to be working together for a shared cause) alongside the use of photography (but not exclusively) as a socio-cultural recording device.

\section{Chapter II: Literature review / context / experience}

\section{Energy harnessing sites:}

The initial interest in the spaces at hand (which I'm deliberately trying to not refer to as clubs) came from realizing the mood and vibe that these spaces can create and generate through human interaction. But it wasn't until I attended Rebecca Wright's lecture on Civilizational Flow: Aesthetics of Energy in a gallery in London (2016) that I started looking at these spaces as energy- harnessing pockets. Wright looks at cities as sites where civilizational energy—ranging from human energy as a means of collaborating, to electricity supplying physical power for machines—can be harnessed and output through different means into 
cultural value. Basically our ability to harness energy and manage it in appropriate ways reflects and dictates our abilities to do things as societies. From these insights I started looking at sonic spaces ("the not-clubs", but rather any space has the potential to be engineered in a sonically conscious way) as places where essentially the above-mentioned energies are at hand and are dealt with through the engineering of these spaces into places. By this I mean how the utilization say of what used to be a industrial factory can turn into a worldrenowned dance music club eg. Berghain or how a dingy little basement in London, know as Plastic People (now closed), could've be turned into one of the most forward thinking music places of its time, putting genres such as dubstep on the map and cross-pollinating entire continents of music through its eclectic DJ residency and on-point nights such as FWD>>. From the sound system rig-the amount of watts being pumped into the speakers through cables and translated into sound wave frequencies that go well beyond our ear range perception-to the way the speakers are placed in the space, to the layout of the space itself, to how people move through it, to the placement of the dj's booth vs dancefloor situation (whether the dj is escalated on a platform or can be seen at all): all of these elements add up to how energy is being simultaneously harnessed in a space and outputted within it and resonated through channels of information. This of course has both direct and indirect outcomes as a performance in a space can have profound impacts going well beyond the walls of the space and into the cultural/societal circuit at large. Socio-cultural experiential events can have a ripple affecting entire communities well beyond the boundaries of "that 
time at that club, patio, basement, etc". These spaces are transformed into places that have cultural meaning, they can carry significant political and sociocultural messages for the participants.

Music Penetrates Everywhere It Carries Words With It It Fixes Them In the Mind It Graves Them In the Heart Music is a Weapon in the Class Struggle - (Lieberman 1995: 28), (Roy 2010:8)

Christopher Small suggests music is comprised primarily of histories of those things, which are works of music and of the people who made them, and these tell us about the circumstances of their creation, about the factors that influenced their nature, and about the influence they have had on subsequent works (Small 1998: 4). He describes music as a process rather than object-the fundamental nature and meaning of music lie not in objects, not in musical works at all, but in action, in what people do (Small, 1998:8). It has been also noted that bass-heavy sounds are the primary sounds we perceive as human beings, as we develop our senses within a female womb, picking up on the exterior low frequencies as well as the beat of our mothers' hearts, embedding bass-heavy, beat-oriented sounds within our human nature (Christodoulou, 2011: 47). Although the intention of the documentary is not to necessarily focus on the history of music and its significance in urban dwelling, it is unavoidable to include some of the socio-political movements that are tightly intertwined with music scenes around the world. The importance of music in political movements is well explored in Sounds of Resistance: The Role of Music in Multicultural Activism 
(Eunice \& Michie, 2013) and it revolves around social class struggles around the world: from anti-apartheid movements in South Africa to the festive shores of Brazil, punk in England, techno in Germany, Disco in the Lower East Side of New York, house in Chicago, reggae in Jamaica. Music has long been a powerful social gluing device that has had tangible importance in accompanying and even shaping socio-political movements.

Lin Tan's dissemination of music culture in Disco as Operating System (2008) goes beyond suggesting that disco was a crucial and vital sound of the seventies that has led to a host of media formats and music styles in the eighties and beyond: house, ambient, electronica, hip-hop, snap, trip-hop, dub, crunk, garage, hyphy, and techno (these mutations suggest how varied and nonspecific disco as a genre became and how complicated its evolution and mainstreaming ultimately was) (Tan, 2008: 83). By the early years of this century, the disco sound had morphed into not only house music but also into production and distribution practices associated with "social media"; its divergent music-making techniques, social venues, low-cost or free distribution models, social practices, and changing technologies made disco not principally a commodity pressed on vinyl and consumed in private and public place but a cultural format accessed in a communal setting where the line between singing and acting, listening and participating, between a celebrity and what Warhol called a "nobody", and between an individual and a network were being dissolved in an era marked by flexible accumulation and the transformation of culture into a fluid species of capital (Jameson, 1998: 73). 
It is important to note that though many music scenes stem from different continents and often have been reflective of the local culture, it is equally important how these origins are being deliberately blurred in today's music, often having seemingly obscure crossovers such as Japanese fusion jazz to contemporary classic drone noise. Nowadays the most established music scenes are often founded on long histories of music legacies (jazz for hip hop/ disco for house etc.), these scenes or rather sounds are being mixed by individuals around the world, creating niche cultural pockets of scenes/ collectives not bounded by physical geographies but rather interpolated from hyperreal spaces of data information. Music culture (especially within urban environments) has a profound role in shaping culture at large, as recognized during the study of the Walkman. Here it was concluded that culture can be studied not only as a series of contents or as a connected set of manufactured devices, but also as an ensemble of practices embedded into modes of production and ways of consuming. The Walkman as a technology product has created a new way for people to consume the music they like individually (with headphones) and therefore a new way to identify and relate to culture, coined here as "privatized leisure" (Gay, Hall, et all, 1997:104). At the time this treble sound ${ }^{2}$ was taking over the world, the sub-bass sonics hailing from Jamaican soundsystem culture that Henriques puts forward in Sonic Bodies (2011) had also been integral in the development of contemporary urban music movements and in their relation to

\footnotetext{
${ }^{2}$ Referring to low quality sound, not equalized cassette and earplug playback.
} 
socio-political conditions at hand. In both the academic world and underground music culture, bass-heavy sound plays a crucial role in contemporary culture.

Mala, one of the pioneers of dubstep music, discusses in his almost two hour lecture with Red Bull Music Academy ${ }^{3}$ the importance of dub culture, sound systems, space and the processes and intentions that go behind such sounds. There is a whole economy of production and consumption that goes into how sound is being integrated into urban living: from using specific timing (140bpm) to cutting dubplates, to appropriating the sounds for specific sound systems, all encompassing the term "musicking" (Mala, 2008)

Without going too much into the historical background of music culture in urban environments it must be noted that it has played key roles in everything from gay movements (disco), austerity outcomes (house/ techno) to bedroom produced sounds invoking the realization of transcendental communication technologies (juke). All comparisons aside, it is evident that contemporary music culture has its own parallel economics behind it, with production, dissemination, and distribution practices becoming more independent. These movements have an unrated significance in shaping today's culture.

One way to look at the topic at hand is through the lens of Deleuze and Guattari's rhizome as conceived in A Thousand Plateaus (1987): treating music culture as having no beginning, middle, nor end, as a fluid growth that spawns simultaneously in many places, as a process that regurgitates itself and transcends all human experience.

\footnotetext{
${ }^{3}$ Red Bull Music Academy in Barcelona, 2008.
} 
Roots don't stay in one place. They change shape. They change colour. And they grow. There is no such thing as a pure point of origin, least of all in something as slippery as music, but that doesn't mean there isn't history. (Hebdige, 1987: 10)

Steve Goodman, aka Kode9 has recently remarked:

"[...]the intensity of new musical forms like jungle required new language and concepts. In other words, music could spawn theory; it could be about thinking and not just listening." He describes Hyperdub, his record label, in the following way:

an info virus [that] replicates in both humans and machines ... Thus began a fictional narrative - the "Hyperdub virus," a sonic form mutating over time ... starting as the idea of a virus but the music wasn't a virus when [he] was writing about it ... and then the fiction became real. You're in the fiction, the fiction is real, it starts to produce real things, real events-and so on. (The Fader, 2015).

Movements such as Hyperdub represent hundreds of thousands of people around the world that actually bring to reality what was, until recently, considered mere fiction or hyper-reality. These notions are very exciting, especially for places such as Toronto where the multicultural heritage can be manifested in ways that create new culture. But these expressions require spaces, spaces that the inhabitants of the city are struggling to find, utilize, and occupy in a way that fosters local community rather than being "hyper-centric" as many have been described.

\section{Contemporary human spaces of engagement | BAR 25 and beyond.}

The idea of looking at "clubs" as more than just clubs as the general population knows them sparked when visiting Berlin in 2009. It was, Bar 25 that my friend's 
mother took us to on a summer weekday. "They are not fond of tourists at this place" I was told (not so much foreigners as cultural tourists, more drunken British lad types of people). The place wasn't just a "bar" or "club" or even "lounge". It had a living three dimensionality about it, photo booths next to rope swings across the river, the steady thumping of dub influenced sounds, an ease of flow through the space and an open attitude of people interacting (ironic given the door policy). Bar 25 had been created by $80 / 90$ s squatters and held strong until 2010 when it closed down, later to turn into KaterHolzig and consequently into Kater Blau in 2014, (all within the same river, all world renowned venues).

Having been exposed not just to Berlin's music sonic spaces, but starting off as a concert photographer in Poland at the age of fourteen and working with some of the most profound individuals and groups in contemporary music across several continents, also while working on documenting citizen participation vis a vis land grabbing in Cambodia during my undergraduate years, I learned that the seemingly polarizing subjects at hand have a lot more in common than one may suspect. It has been only natural for me to start looking at sonic spaces in a similar way as places and spaces in which citizen engagement processes take place.

"The outside is not a fixed limit but a moving matter animated by peristaltic movements, folds and foldings that together make up an inside: they are not something other than the outside, but precisely the inside of the outside." (Deleuze, 1988:96-97) 


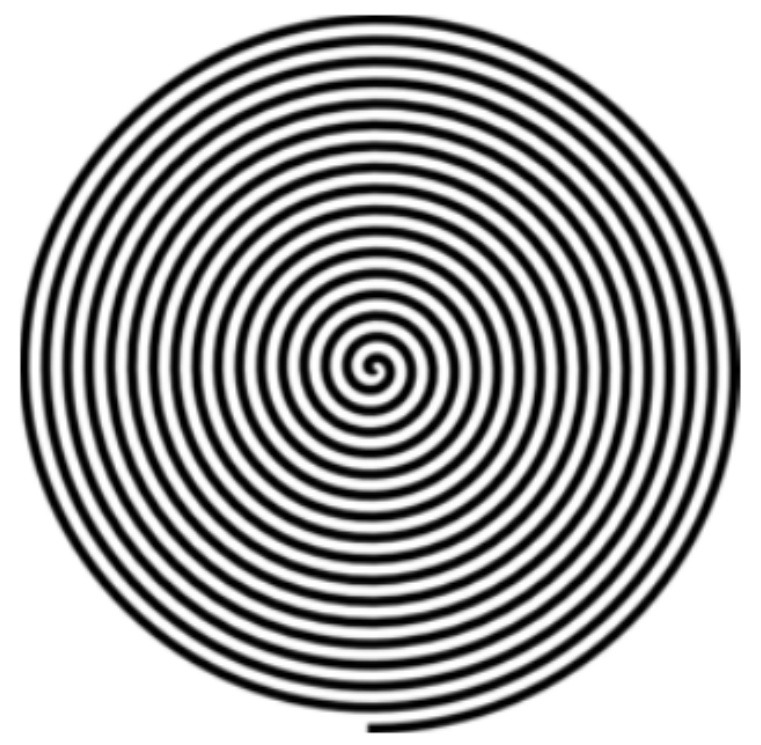

Take responsibility for the energy you bring in-to the space

Ian Good Catherine Hilgers Benjamin Inch 2013

\section{Place / Space:}

Theoretically speaking, at the heart of this project is the notion of public spaces and their utilization/ actualization by the music collectives. Clubs, or rather, spaces with loud music and flashing lights, are being taken into account as public spaces, or as spaces Jose Pedro Regatao defends as territories of political character that reflect the structure of the society in which they operate (Regatao, 2007). 
By looking at urban development vis a vis music culture, we can attempt to stipulate the value of these public spaces, these highly stigmatized and underestimated club spaces in which a large portion of urban dwelling is lived out in whatever capacity: whether it is a venue's staff dealing with the clientele, or the promoter promoting certain values, or simply the people that come and congregate to the sounds that the DJ lays down on them-there is without a doubt a particular sort of tension that is played out in these spaces, and it is reflective of the larger social fabric.

Between 2009-2015, during the time l've been able to witness and access the current state of affairs, Toronto has had, one may say, a bridge to its underground music culture. Though this seems almost as a cyclical condition of the developing metropolitan city, this project focuses on the most recent realities happening throughout the city during these years. Through organizations such as Mansion or Foundry, world renowned (yet non-mainstream) acts would be hosted in various DIY locations across town. Ranging from world acclaimed djs such as DJ Harvey to more underground sounds of Shlohmo or Kode9, it must be noted that there isn't a lack of conscious people within the Greater Toronto Area that make these events happen, but there is a definite lack of fundamental resources and inadequate facilities in the spaces/places where they are happening. Business trumps culture in this city and it's quite audible whenever you enter most clubs. 
In The Production of Space, Lefebvre argues that we need a theory that could examine the realms of physical, mental, and social spaces as inseparably intertwined with each other. He argues that such a theory is needed because Western thinking is still a prisoner of Cartesian epistemology with its contraction of the abstract subjects and its maintenance of a split between mental space and social cultures: "the space of social practice, the spaces occupied by sensory phenomena, including products of the imagination such as projects and projections, symbols and utopias" should be included in this "logicoepistemological" spatial examination (Lefebvre, The Production of Space, 11-12). Lefebvre's theory starts off with the notion that space is a product and all knowledge of it "must be expected to shift from things in space to the actual production of space" (Lefebvre, 36-37). When looking at clubs as invaluable socio-cultural spaces in urban environments one can easily map Lefebvre's recognition of space onto how clubs spaces are created or performed. Lefebvre suggests that spatial practice defines:

"the relationship of the local to global; the representations of this relationships; actions and signs; the trivialized spaces of everyday life,; and in opposition to these last, spaces made special by symbolic means as desirable or undesirable, benevolent or malevolent, sanctioned or forbidden to particular groups" (Lefebvre, 1991: 288)

\section{Music reflective of human condition:}

In The Soundscape: Our Sonic Environment and the Turning of the World, Murray Schafer introduces the book by describing music as originating from two sources. One was invented by Athena when, after the beheading of Medusa, she was touched by the heart-rending cries of Medusa's sister and created a special 
nomos in their honor (music arising as subjective emotion). Another originated from a Homeric hymn to Hermes: the lyre is said to have been invented by Hermes when he surmised that the shelf of the turtle, if used as a body of resonance, could produce sound (music arising as discovery of sonic properties in the materials of the universe) (Schafer, 1993: 6). He further puts forward Hesse's The Glass Bead Game, where Hesse claims to be repeating a theory of the relationship between music and the state from an ancient Chinese sources: "Therefore the music of a well-ordered age is calm and cheerful, and so is its government. The music of a restive age is excited and fierce, and its government is perverted. The music of a decaying state is sentimental and sad, and its government is imperiled" - and as mentioned, such notions suggest that the egalitarian and enlightened reign of Maria Theresa and the grace and balance of Mozart's music are not accidental (Schafer, 1993: 7). Fast forward to 2016 and this theory can be seen as holding its own more strongly than ever: sounds are predominantly being conceived through electronic sources and, importantly, a large majority of music is not only dance- oriented but constructed and output as something resembling highly sophisticated mechanisms, mutated machinery that has taken control of our bodies, dystopic, loud, often discombobulating. These are some of the sounds embedded in modern life. One might go as far as suggesting a post-capitalist digital apocalypse unraveling in front of us, a human condition entering its new era where the state is no longer held accountable, as society has evolved beyond its own borders, as have the boundaries between music classifications. An interpretation of Kedwo Eshun's sonic fiction can take 
on more concrete notions about the contemporary human condition, where highly engineered sounds are brought into music clubs and deployed onto the audience in the same way warfare is carried out: calculated, to the point, relentless and taking no hostages. What we are witnessing in today's clubs is arguably reflective of the human condition and more so reflective of where we are heading as a civilization. Hard thumping kicks, stripped down clashes of hi-hats and buoyant basslines are grasping many societies around the world and taking them on sonic trips, mimicking much of the understood world: fast-paced technology communications, drone-frontier horizons, mechanized production lines are all being heard in the technos, and the houses, the dubsteps, and the footworks of today's musicians. Tribal is meeting the quantized. Just like the aforementioned music during the reign of Maria Theresa, or the sentimental vagaries of Richard Strauss (consistent with the waning of the same Austro-Hungarian Empire), today's music can be heard as a reflection of the socio-political realities around the world. Sonic narratives infused with drone-like warfare sample basses and terrorizing rhythms by artists such as Fatima Al Quiadiri (her most recent album Brute, focusing on the diminishing power of protest in the Western world), is particularly inspired by the recent events surrounding state brutality around the world. The cover, an altered Josh Kline ${ }^{4}$ image, depicts a Teletubby in a police uniform, and the album starts with a recording of a police unit trying to stop a

\footnotetext{
${ }^{4}$ Josh Kline is an American artist and curator. In 2015 His instillation "Freedom" (wherein Teletubby statues stand in the abound in SWAT gear while a computerized version of Barack Obama's 2008 Presidential inaugural address is played was included in the New Museum Triennial, Surround Audience".
} 
protest with an LRAD, a sound weapon that beams concentrated blasts of uncomfortable noise.

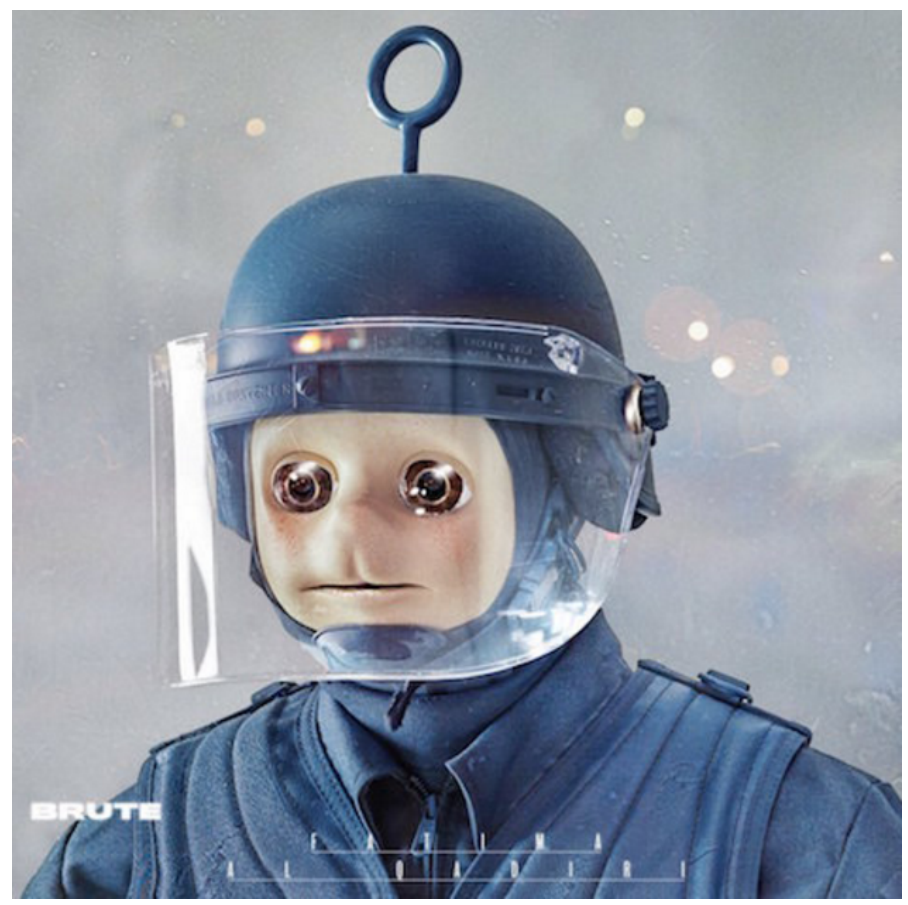

Fatima Al Quaidiri, Brute 2016

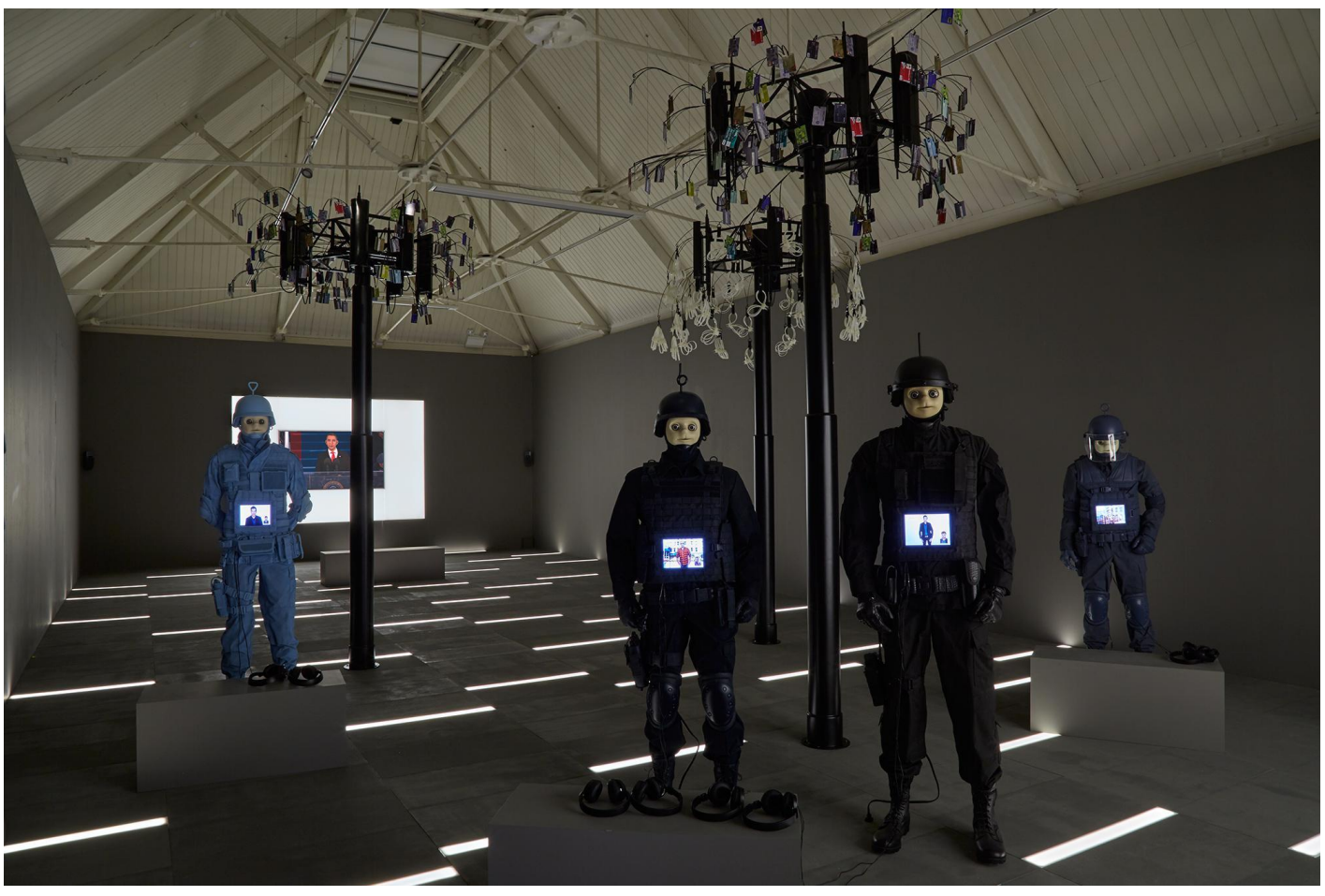


Josh Kline, Freedom, New Museum, New York, 2015

Through her position as a DJ, producer and label boss, techno artist Paula Temple has raised issues related to gender and sexual equality, governmental and societal "control systems" and European border policies, but has kept her brand of powerful, industrially-tinged techno at the center of her message (Resident Advisor, 2015). Kode9's 9 Drones literally sounds like a serious bombardment of a space, where the underlying drum beat comprises of high speed cannon shots, capable of destroying a dance floor: a exemplary so-called club weapon. By looking at such club spaces as public holodecks, we can quickly recognize the importance of what is being projected, the quality of it, who participates, and how these spaces can be regarded as highly sophisticated socio-political forums.

Henri Lefebvre breaks down the science of space in relation to the neocapitalist system and points out that it represents the political use of knowledge, remembering that knowledge under the system is integrated in a more or less "immediate" way into forces of production, and in a "mediated" way into the social relations of production. Furthermore, it implies an ideology designed to conceal that use while the ideology carries no flag, and for those who accept the practice of which it is a part, it is indistinguishable from knowledge. Space embodies, at best, technological utopias, a sort of computer simulation of the future, or of the possible, within the framework of the real or existing mode of production. (Lefebvre, 1991: 9) Discotheques, therefore, should be seen as some of the most progressive technological utopia spaces, where it is not merely a science fiction 
novel being exercised, nor simply people getting inebriated to escapism, but these are real projects concerned with a holistic use of space: architecture, urbanism, social planning, and beyond. Music is an operator in the new forms of sociability, which has clearly been the case from the mass gatherings of the 1960s right up to today's phenomena (raves, for example) (Badiou, Žižek, and Spitzer, 2010: 3). Today music plays an even broader role in sociability, when electronic dance music (EDM) festivals have been overtaking entire cities and the online sharing and consumption of it has become a unprecedented source of cultural communication.

\section{Chapter III: METHODOLOGY}

First and foremost my decision to undertake this project has been largely based on my relentless interest in music, as well as my full-hearted belief in grassroots development projects, or, in other words, initiatives that enhance people's capacity and capabilities as social actors integrated into glocal $/^{5}$ politicaleconomies. Democratizing social organizations through holistic processes, I have entered into Sonic City with the intention of exploring the relationships being manifested and acted out in underground dance music culture. This culture is my platform for investigation of parallel, democratized, socio-political landscapes that encompass entire monads of cultural production, dissemination and engagement in ways that appear to be invaluable in today's world. My

\footnotetext{
${ }^{5}$ Reflecting or characterized by both local and global considerations. Eg. Web 2.0 where local contributors add up to global realities, or how local food laws impact global markets.
} 
approaches have been based on methodologies developed by researcherpractitioners such as John Gaventa, Andrea Cornwall, and Bettina von Lieres, who mentored me in my practice as a participatory research action photographer documenting the Sam Rainsy opposition party leaders in Cambodia during the years 2009-2012. There I witnessed and learned about the importance of places and spaces in relation to socio-politcal manifestations. Where my Cambodian work focused primarily on struggles of the general population against the country's tyrannical governance (manifested via land disputes), in Sonic City, underground dance music culture has been my platform of reconnaissance of the highly contested urban lands of Toronto and London. The practice I am continuing as a documentarian is embedded the in interpersonal, grassroots community-building lessons I learned in Cambodia, where as an outsider interested in becoming an insider, I am aware of the complex yet fragile sociopolitical networks involved in generating monads and take on the practice of cultural integration.

\section{I-Travel:}

My research on civic engagement, social capital, and social democracy building has been rooted in international development and civil engagement methods, closely associated with the works of John Gaventa, Andrea Cornwall, and the Institute of Development Studies in the UK, alongside personal experiences of working in the field in Cambodia with political opposition campaigning. While l've been observing and testing out development practices in Cambodia over the 
years, leading media workshops for communities, documenting events and showcasing them to the relevant publics, I recognize the importance of participatory practitioner/ researcher methodologies. As a result I have integrated these approaches into the core of this project. By looking at music culture and its relationship with urban development, I have taken the time to know the community, gaining trust through accountability and transparency, blurring the lines between researcher and practitioner, and engaging subjects into matters at hand. In this way I have developed a vital network of individuals and communities either leading bass-heavy dance music scenes or slowly taking on the roles of future leaders. The passing on of the torch within dance music production is a key element in shaping the integrity and democratizing music culture at large, an aspect I've been trying to exercise onto myself as a self proclaimed DJ and music nerd.

In 2015, taking my first conscious steps in developing this project, I travelled to London, UK with the hope of diving in deep into the world's most notorious/ famous underground music culture and trying to navigate for myself amongst all the chaos that comes with it. Having set myself a plan of visiting vital locations (eg. the Elephant and Castle, the place where the first Garage music record was played out and which over the period of doing my documentary had been under the siege of Foxtons ${ }^{6}$ development project), and meeting collectives and individuals that are on the forefront of contemporary dance music culture, the five months I spent in London have been not only been quite surreal as much of the

\footnotetext{
${ }^{6}$ Foxtons Group plc is a British estate agency company dealing with both lettings and sales. It is listed on the London Stock Exchange. In 2014/2015 there was a
} 
documentation process was happening at odd hours of the day, but more so I managed to get close and personal to figures such as Kode9 [HYPERDUB], Loefah [SWAMP81 $\left.{ }^{7}\right]$, Ashes57 $\left[\mathrm{TEKLIFE}^{8}\right]$, J.Tijn $\left[\mathrm{WNCL}^{9}\right]$, Boiler Room ${ }^{10}$ editors, Jim Warboy ${ }^{11}$ (LGBT club pioneer in London) and many more. All are part of complex cultural networks revolving around music, pumping data/information fluid into the city's vast bloodstream. It is worth mentioning that the time spent with Professor Steve Goodman (aka Kode9) has been the most eye-opening, in terms of encroaching myself even more into the music underground, and much of my research going forward has been based on our conversations about sonics', use of frequencies to persuade crowds or disperse them, and the transmorphing of socio-cultural energies into actualized events, communities and movements around the world.

If there is one thing that contemporary dance music culture knows how to do it is organizing itself, after all "the show must go on", and there's no lack of keeners willing to go above and beyond to make it happen. There is great resilience within music culture and it is expressed through various processes and actions; from gospel singing in churches to voguing dance-offs in LGBT fam houses.

\footnotetext{
7 SWAMP81 is a record label based in South London, an imprint run by DMZ's Loefah. Named after Operation Swamp 81, the stop and search laws put in place in 1981 throughout the South London area of Brixton and which directly lead to the infamous race riots of that year.

${ }^{8}$ Chicago based footwork record label. RIP DJ Rashad.

${ }^{9}$ West Norwood Cassette Library runed by Bob Bhamra aka WNCL.

${ }^{10}$ Boiler Room is a music platform that hosts intimate live music sessions with an invite-only audience in mostly private locations, streaming the performances live on the Boiler Room website and through video streaming services such as YouTube and Dailymotion

11 Warboy has become firmly established as a leading figure in London's club scene over the past decade, having been closely involved in some of the city's most definitive experimental nights.

'Warboy remains one of alternative clubland's greatest forces who is constantly ahead of the curve'. (DJ Mag)
} 
Music equipped with an agenda has the ability to ink the social fabric in ways that slowly but surely changed its colour. As with many, it can be seen that this is spearheaded by the intrinsic nature of musicking, where the act becomes cognitive praxis: knowledge-producing activities that are carried out within social movements (Eyerman \& Jamison, 1998:7).

To interact, people must orient themselves toward others, not only in terms of intention, but also in terms of what is going on. Precommunicative interaction is especially clear in nonverbal interaction such as team sports, dancing, walking on a busy sidewalk, making love, and doing music (Roy 2010:15). "Tuning in" thus underlies the relationship in specific dimensions of time (Schutz 1964: 173), and the communal act of attending many underground dance music culture events revolves around vibing it, tuning into it. However, taking this logic further, music is not a non-social activity in a social context but is context in and of itself as Seeger explores in Why Suya Sing (2004), and this context has been explored by me through navigating between the real and the hyper-real; between research in record stores, dance floors, interpersonal conversations and then in between online discographies, articles, YouTube links and world connectivity.

\section{Finding subjects:}

Despite being a huge music fanatic, up until actually starting to develop this project in 2015 I have not had an "in" into the underground that I've been exploring throughout these past 15 months. First and foremost I spent a great amount of time listening to music before formulating any kind of strategy towards 
the approach to my subject. I spent countless hours first in clubs, then in music studios; I knew I had to be known by some individuals to get to know others. I had to show my commitment to what is happening online and offline. For best practices, and in the interest of the longevity of this project, I had to go with finding out more about music that has had a great influence on me, the people behind it and the places where it all happens. This meant exploring both the information/ data side of things as well as the physical and metaphysical vibration side of things, where approaching individuals or entire collectives would be based on my musical contextualization skills as well as time limitations. Briefly, knowing about "Toronto's techno daddy" Brian Wong aka Gingy ${ }^{12}$, a local yet globally recognized young figurehead of music experiences, I managed to set myself up getting connected into a vast network of people making the underground dance parties happen in both Toronto, Canada, and in London, UK. First through email and phone, then largely through interpersonal interaction, I jumped between noise fused techno shows in Toronto basements, hardcoreelectro gay nights in dungeons in London, hallway-sized radio stations in Toronto, mammoth carnival clubs, and private producer get-togethers, where I would be slowly making connections between music production, dissemination, and consumption.

\footnotetext{
12 Every party the It's Not U It's Me collective has thrown feels like a fever dream - otherworldly music delivered in an equally unexpected space. "I dunno, maybe I'm psychotic," Brian Wong responds, when I ask him what drives him to seek out such unique venues. "But for me, the moment you're approaching these shows with an attitude of complacency, it's over. You need to be ready to blow people away on a pseudo-religious level." (Brendan Arnott for Juno Download, June 27th, 2016)
} 


\section{Large format photography:}

Taking up the $4 \times 5$ camera was for me what l've been explaining to musicians as: "cutting my own vinyl, large format photography as the equivalent of record grade sounds but photographic". The effort to "Alex-Soth-away"13 with a $4 \times 5$ camera onto subjects that are far too elusive, mobile, evasive, underground, even mythical-all of which makes it truly difficult to even get access to certain individuals and spaces-is meant to be my personal homage to quality musickers. By indulging into the physicality of black and white $4 \times 5$ sheet film I am attempting to be reflective of vinyl-rooted sound systems, putting in the physical labour and time that is associated with truly independent and unrestrained record labels. Each sheet of film represents the fact that I had to physically go to the people, places, and spaces- where the constantly shifting rhizomes of musicking happen by real people in physical dimensions and through physical interaction. The $4 \times 5$ sheets are meant to be glimpses into the vortex of data/information, time/space, energy/ sweat that occur through music culture. Acting as environmental portraits, the portraits are person/place dependent; they were created through me traveling with the subjects to places/spaces that are sonically sentimental/ crucial in the development of their own work/life. Taking these portraits is meant to be a reflexive process, a process representing not merely the act of djs carrying tons of vinyl, the sleep-deprived sound crews setting up

\footnotetext{
13 "In a sense, I take a lot of inspiration from the journalism that came to prominence in the 70s where the journalists didn't speak in the third person, it's like they are essentially a character in the story. While I don't necessarily turn the camera on myself - I don't want to sound like I have some authoritative view - I want to feel like a piece of the story, because I am." http://www.dazeddigital.com/photography/article/29511/1/how-to-tell-stories-through-photography
} 
systems, the producers field recording samples; but also a process of exercising social capital and building within it.

Rooted in citizen political engagement, community strengthening, and accountability, this is where the documentary $\rightarrow$ development / development $\rightarrow$ documentary conundrum occurs in this project, and this is the exciting duality within my practice, where on one hand the simple act of focusing the lens on communities alongside sharing the footage (very important to give footage back to community) fortifies the so-called social glue of it by stimulating it and acting as a reflective mechanism for individuals. This type of grass roots work is widely spread in developing countries; whether in exemplary Brazil, or post apartheid South Africa, many civil movements have utilized media content as self reflexive and self-emancipatory tools for the most marginalized communities. This of course requires not only a conscious use and understanding of media utilization but also needs to be appropriately carried out.

\section{Field recordings | Mixing techniques:}

The idea of field recordings seemed a pretty obvious solution for me, as at the core of this project is the notion of spatial environments and the significance of sound occupying/ living in these environments. Parallel to this is how our bodies behave in them-how our bodies are reading the environment and reacting to it whilst being immersed in a concentrated socializing space.a space where human bodies intermingle in the most acute of ways, through body movement and energy output. At first I would be doing field recordings simply during the 
time l'd be taking large format portraits of my subjects. I wanted to capture the sound of capturing the portraits (setting up the camera, casual talk, the shutter speed, the environment it was taken in). Soon enough, field recordings were being taken in the streets. Ridley Market was the first stop I did with a shotgun microphone, and I progressed into recording multiple spaces/places: outside of clubs, inside of clubs, dj booths, neighborhoods, transportation, and sheer room noises. I have built a library of sounds which I intend to use to develop an elaborate soundscape compromising music, field recordings, and interviews to create sonic narratives reflective of my process and the subject matter.

As a way of tracing and contextualizing some of the music scenes developing in tandem with one another, merely fragmented pieces of the larger rhizome of contemporary dance music, my documentation for this thesis will contain a 22:44 min sample of the soundscapes that were taking place within the installation. The soundscape mix consists of interviews carried out by me, all besides Daniel Levitin's points on music as a neurological cognitive device which was taken from The Agenda with Steve Paikin in 2010 (The Agenda, 2010).

The recordings include:

Daniel Levitin (CAN): speaks about music and the brain.

Adam Marshall (CAN): founder of New Kanada records, a world recognized music label now based in Berlin (GER) but originally from Toronto. He speaks about why Toronto is behind the world with dance music spaces, largely because of funding and the lack of recognition of "new spaces", between art and club. 
Eleni Ikoniadou (UK): looks at how we perceive time and duration when considering our cultural world, and the paradox of physically and spatially experiencing digital art, phenomena that are becoming ever so intrinsic into global urban dwelling. This is a recording from a talk she gave in London in 2014. Jim Warboy (UK): One of the pioneers of LGBT events in London, veteran in creating edgy and direct dance culture in and outside of the UK.

J.Tijn (UK): 24-year old Jesse Kruye is a techno producer and DJ that plays in some of the best established underground venues around the world. He speaks about the roots and origins of his career in music.

Venice Calypso (PL/UK): Polish transplant in London, speaks about what DJ'ing is for him and how scenes differ in crowds and attitudes towards music.

Kode 9 (UK): Professor Steve Goodman is the author of the MIT Presspublished and world acclaimed Sonic Warfare: Sound, Affect, and the Ecology of Fear (2010) and he speaks about sonic viruses, rhythm analysis, democratization of wealth, and rave culture.

\section{On-ground research.}

I've been involved in music, or musicking as Small ${ }^{14}$ would refer to it, ever since I could walk. l'd be the child that the mum loses at a mall only to find him either in the bookstore or music store- usually holding a stack of CDs and asking the staff to turn up the volume whilst bumping his head. Needless to say music has been

\footnotetext{
14 Small, Christopher. Musicking: The Meanings of Performing and Listening. Hanover: $U$ of New England, 1998
} 
integral to my life and has had a profound impact on how my brain deals with data/ information and rationalizing it.

The first conscious steps I started taking with music were in conjunction with my street photography, which was my preferred coping device as a kid who had been moving from continent to continent. Being able to play out a "life soundtrack" was crucial for me to find myself in foreign places, whether it was in Poland, Korea, Singapore, or even later during my undergraduate years back in Canada. I was always able to create a sonic space for myself, which would feed me ideas. Ideas were what l'd at first reflect in my photography (mood narratives) and then eventually would get into discovering the world of dj'ing, mixing, sampling, and so forth.

During the years 2009-2014 I went from having dj jams with friends in a basement to hosting a radio show called Space Case at UofT Mississauga campus where we'd have a curated guest mix alongside hosting interviews and opinionated talks on music releases and current events in the city. The first short doc video I did on music culture was with Daedelus [Brainfeeder], a multiinstrumental electronic producer from California who pioneered the Monome instrument. We spoke about communication technologies enabling producers to reach the world from their bedroom studios and how that has been revolutionizing not only music production, but its dissemination and ability to engage people. 


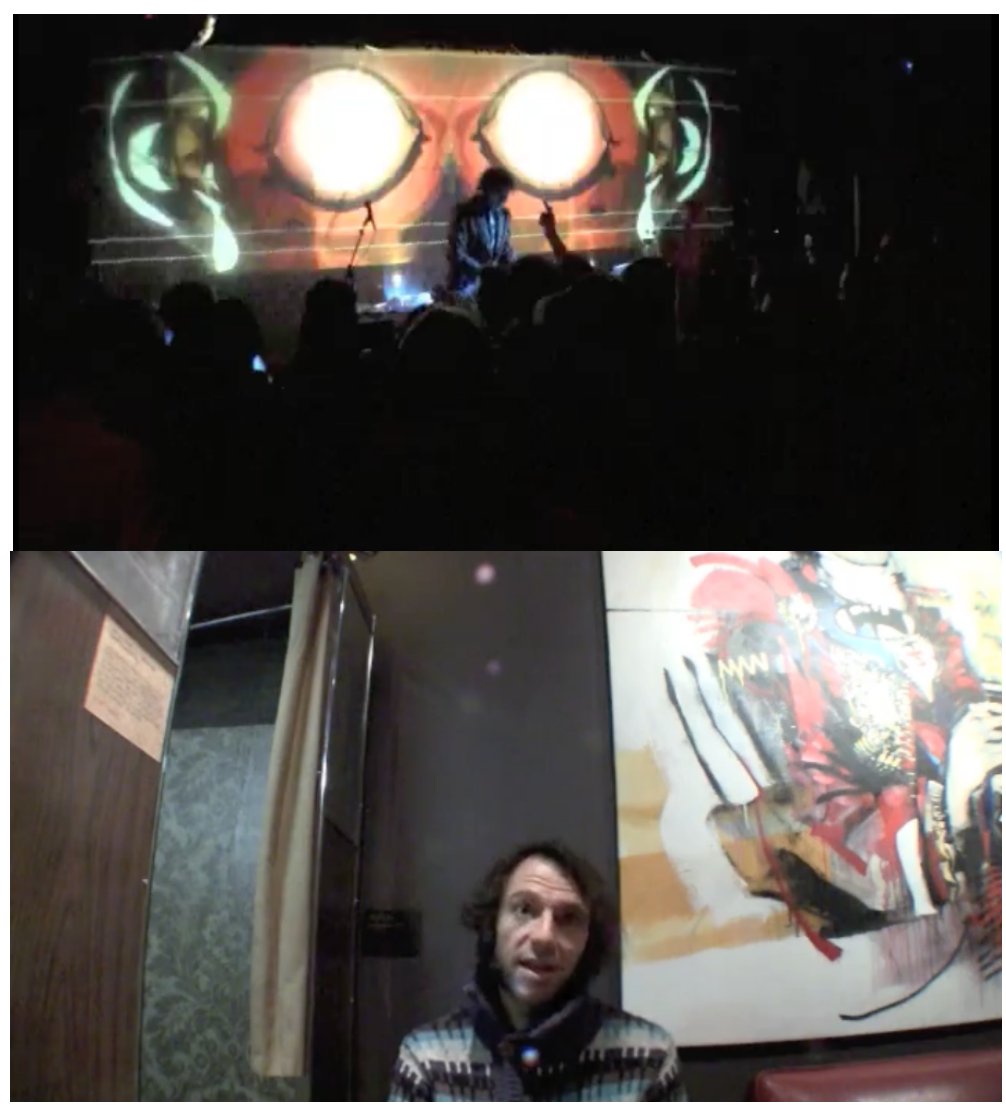

Daedelus at the Drake Underground, 2011

Over the years it has been clear that communication technologies have empowered many marginalized music producers who would otherwise not have had the exposure nor channels to become what they are now: world renowned record label owners, djs, producers etc.

Along with my involvement in music, naturally, I started playing shows in clubs, organizing independent events (from house parties in the suburbs to large clubs in the city) and with that came countless hours organizing dj sets, dealing with venue owners, gear, other djs and so forth- immersing myself in the lifestyle of contemporary djs/ producers which has allowed me to understand the sociocultural nuances involved in shaping it. Being involved enough to get a taste of 
realities but not so much to be defined as being associated with any particular movement has allowed me to play out the role of outside/insider, often allowing my subjects to forget that I'm doing a documentary and enabling me to retrieve information from them without imposing (or at least minimizing) a media gaze in our interaction. Playing the dual role of ethnographic researcher and music practitioner has been central in developing meaningful relationships with different communities and individuals in Toronto and London as I explored these cities, but also virtually in L.A., NYC, Chicago, Shanghai, and Singapore through the connections l've been making, giving this documentary a truly glocalised platform for further exploration and collective engagement and integration.

\section{Appropriating international development models into documentary practice:}

My thinking about socio-cultural urban space relevance has been largely informed by my previous photographic engagement in Cambodia, where I've been exposed to relationships between people, land, and how spaces and places matter as channels of communicating and engaging the public with political matters. In many cases the lessons were obvious: democracy is a process not just an outcome; civic engagement is highly dependent on inclusivity and the ability of individuals to exercise freedoms in adherence to other individuals. Geopolitics of places of engagement matter as well as the actual spaces where people are congregated- who participates, who is invited / recognized, who is looking over... This ethos is being brought into my practice as a documentarian, 
recognizing the significance of working together with people rather than having to work "over them". The point of documenting isn't for sheer documentation, but more so for active engagement. Throughout this project I have taken effort in engaging my subjects into matters at hand, whether through sharing footage online or through meetings or engaging people through showing prints at events. I've always had great respect for essayists / photographers who go far beyond merely documenting events and who are able to unveil multifold truths, experiences that stem from a personal curiosity but can translate into universal truths. This includes about the human condition, qualitative truths, and emotional truths. This has been at the core of my practice as a photographer and has been largely demonstrated in my ability to capture decisive moment. However this approach has been extended into my holistic documentarian approach, where in order to get to recognize these moments I need to be fully engaged with the subjects at hand. This means that unfolding truths require time and perseverance, and interpersonal contact alongside objective viewpoint. The insider/ outsider role is crucial in percolating these truths and can only be done through full engagement.

What I have been chasing with photography since my earliest moments of being involved in it has always revolved around capturing moments reflective of a state of being, or many states, many beings, but always framing up in accordance to my deep rooted interests in the human condition. This condition is shaped by its environment, and in the case of Sonic City, by multiple conditions that seemingly morph into clusters of music culture pockets around the world, shaped by one 
another. The rhizome'ness of music culture via technological communications is to be noted as the basis for figuring out my installation methodology which is meant to inherit these attributes to its own form as a multimedia exhibition event. Documentary / Fine Art are crafts that require work undertaken, miles walked, texts read, and conversations to be had. Approaching this project has been extremely difficult as I find both the topics at hand personal yet mythical, absurd yet obvious, both in terms of production methods and philosophical thoughts. Drawing the line between "these have been my experiences" vs "these are universal experiences" vs "these are experiences that need to be brought to light and recognized" has been what l've been juggling in this project. On one hand I want to have authorship over the work: all content is shot by me, edited by me etc; while on the other hand I want to make it relevant to the large scheme of realities: those of the music scenes and beyond, creating shared authorships.

\section{Virtual reality + real life integration.}

\section{Hosting events for community with community:}

So far I have hosted two events where my photography was exhibited alongside music being played by the people being portrayed in the photography itself. The first event in 2015 was a set of photographs associated with one of the acts playing [MarcoWeibel] and the 2016 event integrated an expanded layout of images with more artists being displayed, cross-referential themes (dance, production, space, radio, marginalization, behind the scenes].

See Appendix 1.1 


\section{Integrating social media with documentary exposure:}

Over the time of shooting my content l've been using social media to group together behind the scenes and other relevant materials.

\section{http://notyourcommonfolk.tumblr.com:}

\#notyourcommonfolk \#soniccity \#socicitytoronto \#skoczkowski and appropriate “@”s in accordance to whoever was involved in the process. See Appendix 1.2

This has been a crucial process in enabling me to step out of being merely an observer/ fly on the wall and has been useful in making connections between myself, the project, and collaboration. Often on the basis of non-monetary exchanges, l'd be able to interact with my subjects, interview them in one way or another, and make use of the immediacy of tumblr/ instagram/ facebook in surging through the vast amounts of data/information that l've been facing. In this way I not only stand out as someone to be taken seriously by the music world, integrating it with my transparency as a documentarian and adapting to many platforms for engaging audiences.

\section{http://spacexlife.tumblr.com:}

Since last year l've been utilizing this site as a space to gather and share research topics with the individuals and collectives I've been approaching as a means of engaging interest. 


\section{Chapter IV: DOCUMENTARY RELEVANCE}

\section{Influences:}

Last year Wolfgang Tillmans put together an "exhibition" of listening to pop music on a high end stereo system. In an interview for The Guardian he speaks about music:

In my life music functions on a par with art - it evokes similar feelings and understanding of the world,[...]l don't feel that the complexity and quality of a record is represented in the way that artistic thought is represented.[...]Some people would say why would you put pictures from a nightclub in a gallery, but I thought these were important moments. They can be fleeting but also a profound and fundamental human experience, both at the same time. The best pop is on the one hand light, but on another it encapsulates the whole world. (Needham, 2014)

Similarly to Tillmans, my own affection towards music and its integration in my daily life has led me to connect certain notions that audiophiles would consider sacred: from needle quality vs vinyl grade, to the three dimensionality of spaces and the considerations of sound intention within them (e.g. for sonic dominance/ sound bathing or mere mood setting as background touch; all meant for different kind of social activities). Regardless of the activities, spaces can be occupied by sound in ways that have profound implications on how people behave in them: ranging from sound waves being possible means for torture (as pointed out in Goodman's Sonic Warfare) to sonic baths associated with religious mantras (used by Buddhist monks). 
The work I am creating in my project is coming from a similar place as Tillmans' work, and with a similar intention: to create site-specific installations where the space at hand will dictate the editing of the produced footage and its reappropriation into a relational exhibit. The intention is to experiment with the interplay of contemporary counterculture, academic institutions, science, and art, where the exhibition/event will use sound, visuals and space to tell a story about musicking and its importance in urban development. The project is intended to be self-reflexive in the form that the exhibition space will be the space where musicking will be happening (as sound performances), hopefully intermingling the preconceived notions of art exhibition (white cube) space and socio-cultural sonic space (DIY music event: warehouse, block party, rave).

Though mainly influenced over the years by photographers such as Christopher Anderson, Larry Towell, Trent Parke, Bruno Serralongue, or Tim Hetherington, my more recent sources of inspiration derive from various practices, some of which are embedded in hyper realities, as these are the spaces/ places (non-places) where much of today's culture is "happening" or "taking place". This of course is not exclusive to internet spaces but is being translated into physical places where sound, visuals and space can create their own kind of hyper reality. Having said so, the above-mentioned artists have influenced my approach to creating images as a photographer and more so recently as a documentarian. First and foremost it must be stated that my work attempts to hold to its own as non-manipulated, non-cropped, and for most part candid street photography: a practice of encountering and reacting, decisive 
moment capturing. Only recently have I been taking set up portraits of subjects, looking at producing and using image-objects, or experimenting with screen shot imagery, something I am exploring more and more as I attempt to tie in conceptual ideas with factual places, events, and people. As my practice has been largely rooted in street photography, where I theoretically rely on Debord's practices of the dérive- drifting through places and spaces without preconceptions or calculated movements, I have exponentially shifted my approach to more conceptualized image constructions where place and space play a double role in the narrative. This is meant to both expose the direct relationship between the subject at hand and the indirect connections between contemporary human development, arts, and politics. In the past months I have been influenced by artists such as Lorenzo Virtuzzi, Alfredo Jaar, Wolfgang Tillmans, Mark Neville, or Katerina Cizek; but also by an array of music record label art, often dealing with conceptual notions on futurism, hyper reality and heritage.

I am attempting to situate my work in between notions of white cube, do-ityourself action, and socio-political forum. By using relational aesthetics the intention of my practice is to demonstrate certain relationships between space, sound and culture (urban development in this case) in a way that is participatory but emphasizes the notion of contemplation and discourse within a space that is sonically active and physically reactive by the participants' presence (or lack thereof). In a way I am trying to recreate a sonic soup kitchen (Rikrit Tiravanija, 1992) but without claiming to have the event as the art in itself but more leaning 
towards a local community ripple effect. A notion starting possible politics-tocome, or what Brian Massumi and Erin Manning refer to as relational soup: a practice for generating events where you can create speed conversations (like speed dating interactions where information is quickly exchanged between individuals) which creates a "idea buzz in the room". These groups of speed chatters are then connected with other pods of people that are also buzzing with a related discourse enabling contextualized conversations to happen on larger scales and with a certain focus in the air. Massumi and Manning argue that these creative approaches to physical activities within contextualized spaces (occupied by art) are effective in creating potential new forms of engagement and participatory politics: practices and processes I find essential when considering using art as a means of communication and output (Relational Soup, 2014).

Having recently seen and exhibition "We Want More" at The Photographer's Gallery in London, which looked at contemporary music and photography, I've been quite inspired to break the conventional ways of portraying/ exhibiting music. From flashing people in dance clubs to creating alter-ego personalities through photographer-artist collaborations, the exhibition seemed in dealing with music's role within culture at large. Despite some great photography it depicted music as something there, happening in the clubs and concert halls, rather than something transcendental and encompassing arguably all aspects of life (rhythm, cycles, beat). The gallery is still very much a place where there is a superimposition of "us" and them" and "here" and "there" states of interaction and interpretation of subject matter. The aim of my documentary 
practice is to blur those lines and confront people's identities and thoughts of freedom in quite literal ways: by incorporating sonic dominance, visual immersion, and a sensory-altering installation that ties in directly with the subject at hand. By incorporating an actual sound system with the instruments involved in contemporary music performance and the people that are involved in music (in this case Toronto talent) the viewers' individuality will be confronted as part of the exhibition. The idea is to create a situation where people will be questioning whether they can dance since it is an exhibition or perhaps letting dance take over and bring that attitude to the table. I see my documentary exhibition as hybrid display of information and human participation in producing/ consuming information: whether through body movement (dance), instrument mastering (live show/ dj), of multilayered discourse (the buzz in the room; what people are talking about, how, what energies are being emanated). The exhibition space is meant to turn into a documentary about musicking so it only makes sense for there to be musicking happening.

The idea is to bring in local producers, djs, record labels, equipment and personalities that are at the forefront of musicking in Toronto (and respective cities), and have my photography and visuals to serve as a contextualizing background for their performances. On one hand viewers will see the places and spaces where these dance events take place, while on the other hand they will be witnessing and participating in a space-the exhibition-as a mimicked space of the subject matter. Rather than treating the exhibition as a escapist space, detached from the realities engraved in the project (in realities at large), the goal 
is to blur these lines and bring the orthodox exhibition setting into the dance space and vice versa, bring the subject of dance music into the exhibition space, creating an integrated platform for cognitive discourse.

Though I have made great strides in getting to know the scenes, venues holders, sound system developers, producers etc, tangible plans for incorporating all of them in the show are yet to be developed- but the chances are good many will be involved in one way or another. The grassroots component behind this project will come through with time: meaning certain expectations I have for the exhibit will be brought together by multiple parties which I hope will be willing to collaborate with me. I have already created a popup event/exhibition in May that has planted seeds within the local music community about this project. Besides exhibiting the work in June it is planned to have one or two more pop-up exhibitions to reach out to interested audiences beforehand and create buzz within the city leading up to the main exhibition. During the next months it will be crucial to create a web-zine/ magazine that will contextualize the documentary in a photo-essay form, allowing the reader to strip down the actual exhibition to minimum didactic text, and having the body of work be translated into a palpable, readable object.

Although the documentary is grounded in photography practice: street photography, candid portraits, use of medium format and large format, I have expanded my usual approach to multimedia recording ranging from taking audio field recordings to glidecam video camera operation and GoPro recordings making this truly a multimedia body of work that can be adapted into multiple 
forms. Besides the zine, four audio podcasts will be created where I will attempt to sonically contextualize the documentary, from my personal involvement with music to talks with people about the ideas behind the notions put forward by the project. This will allow me to not only literally give voices to people but also exhibit crucial sounds, songs, and vibrations that all tie into concepts being discussed. In many ways I have been shifting my process of storytelling from pure image based production to multimedia production-usage, where I am trying to take on more complex relational forms through symbols embedded within music culture and disseminated at large. By developing relationships with my subjects and by acquiring skills on music production I am able now to utilize my media content in concert with existing realities of the music world into generating relational narratives formed from within the subject matter. My role as a photographer and researcher expands into participant and amplifier of subject matter I am trying to convey. Often through juxtaposing the sonic and the visual, I've been experimenting with notions of constantly changing perspectives and this has been demonstrated in the exhibition event where the supply of sounds through invited DJs vis-a-vis two looped video playbacks ( 11mins each), a photo-wall, and most importantly the sonic bodies participating, the rhizomatic nature of these subjects is showcased through the development of rhythm and perception within the exhibition space. As such, the work of Lorenzo Virtuzzi has been inspiring me to take on creating image-objects, but rather than create expressionate art pieces as he does, I intend to further develop my practice into creating indexical photo prints that have to do with music production, 
consumption, regurgitation and so on. Virtuzzi's Dalton Anatomy, inboth book and exhibition installation form, are sources of reference for the current process of conceptualizing my own work. Although uncertain how actually community engaged Virtuzzi's work has been, I intend on using similar practices of having objects and their owners/ users be involved in the process of producing documentary work. Whether by lending equipment that I will photograph or coming up with ways of using machines in the exhibitions, the translation of music scene vibes will be achieved through working with the subjects at hand in a push-me-pull-you sort of way. With sourcing and collaboration at the core, the project goes beyond mere documentation and into a self-documenting process of enabling musicking.

From a documentary perspective, the point of my project is to blur certain preconceived notions of how to communicate: the intention is to integrate the subject at hand with the audience and vice versa. Through location specific installation, performances and multiple didactic forms the documentary has the potential to develop into something beyond orthodox conceptions of what a documentary is, and can use many contemporary platforms to effectively communicate specific aspects of itself, creating parallel modes of communicating the project to audiences both near and far.

\section{Real world springboard platform:}

From the beginning of this project the aim was to integrate its longevity into the lives of the subjects. To do this I have been working closely with ItsNotUitsMe 
(INUIM) collective in Toronto and have now been offered to exhibit alongside their Power Plant 2016 takeover which will involve three day and night events during July and August where my project will be integrated as an installation. This is a great opportunity not only for me as an artist but more so a new form of bringing documentaries to the public's attention. By interweaving Sonic City into large scale music events with international acts, the "glocality" of the subject matter can really start to be exercised. Just as during the opening exhibition for DocNow, where local artists alongside visiting ones had the opportunity to exchange experiences and showcase themselves through the exhibition, the photo wall acted as the "Torontology" (as some have called it) or local artists along with the juxtaposition of UK's leading figures created a truly "homie" reflection, a key trait at the core of these music cultures.

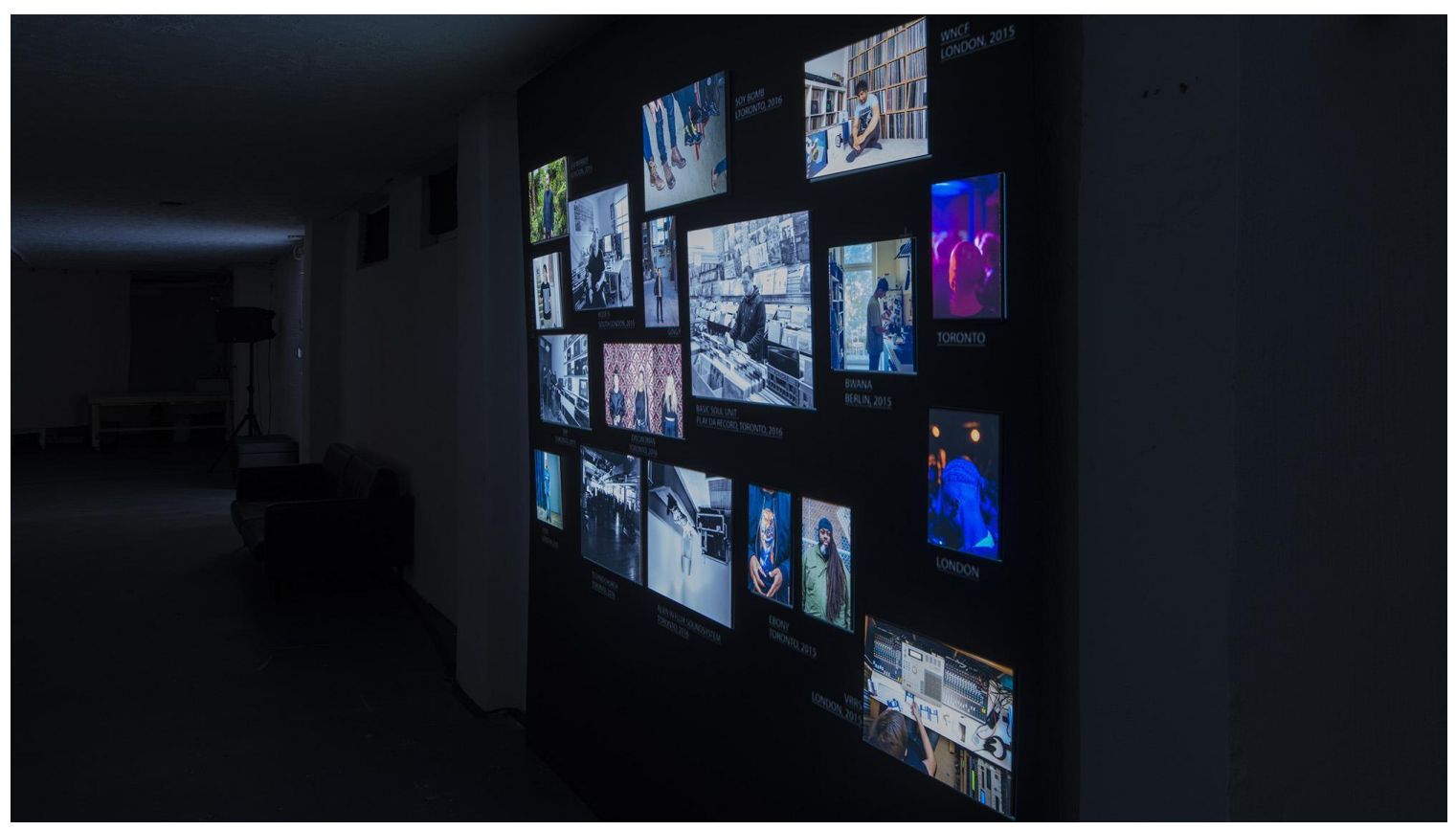

Photo wall at Rally, opening exhibition of Sonic City, 2016 


\section{Conclusions:}

Having gone out as a music enthusiast into the depths of underground dance music culture in hope of finding out more about its relationship with urban development I have taken upon a comparative approach, looking at Toronto's upcoming dance music scenes and London's already well-established ones, in order to seek out their roles within the urban context. For one, it goes without doubt that the establishment of this culture is highly reliant on the participants putting energy into it as well as access to spaces- where this culture can be actualized. London, known for its civil participation history has had decades of experience in civil society organizing itself, a contributing factor in both enabling dance music culture to develop as well as holding its own ground by establishing venues and generating the culture behind it. Toronto on the other hand, as a relatively new city, with arguably much less civil society experience is struggling with communicating community needs to the government, crippling its capacity to develop the multitude of culture vibrating here. Secondly, dance music culture takes on many forms, forming multiple scenes which in one way or another rely on one another. Whether its soundsystem dub reggae nights in South London, or warehouse techno parties in Toronto, these groups have the ability to communicate with and influence one another in ways that can make them political. The mere organization of communities, the imposition of data/ information through the speakers, the submission of sonic bodies to it, makes these music scenes political in one way or another. From squatters establishing exclusive Bar25 in Berlin, to ultra big EDM festivals, which attract hundreds of 
thousands of people from around the world- the spaces being occupied by music, dance, and society become politicized places, each with their own rules of conduct, each contributing to the democratization of culture. 


\section{Glossary:}

discotheques - places with loud sound and flashing lights where a disc jokey or producer is responsible for providing dance music and maintaining a certain atmosphere in the space.

dubstep- 140 beat per minute (BPM) bass centric electronic music originated in Croydon, London by Digital Mystikz collective (Mala, Loefah, Coki).

electronic dance music (EDM) - a commercial take on dance music involving the adaptation notions of dance music culture into the world of pop-culture entertainment where hundreds of thousands of people participate in the monopolization of music stages by several cookie cutter producers and djs. The Coca-Cola of liquid hydrations options.

fam houses- family-like collectives of LGBT dancers and performers, closely associated with vogue dance culture

garage music - originating in the United Kingdom in the early 1990s, features a distinctive 4/4 percussive rhythm with syncopated hi-hats, cymbals and snares. Garage tracks commonly feature "chopped up" and time-shifted or pitch-shifted vocal samples complementing the underlying rhythmic structure at a tempo usually around 130 BPM.

glocal- processes involving the participation of local actors with foresight of global impact.

grassroots development projects- human capacity enhancing development programs directly involving the stakeholders in regards to their own socioeconomic situation.

hashtagging- grouping and organizing online content for best communication practices.

holodeck- in reference to Star Trek's virtual reality facility, a space used to recreate familiar places, participate in interactive stories, and practice various skills. In this context clubs are seen are sonic holodecks for people inside, where dance music becomes the audio-nerve stimulator taking people on their own journeys.

human development- holistic living practices involving the utilization of socioeconomic resources for the benefit of mankind in regards to the environment.

hyperreality- through overflow of data/ information technologies it is becoming more and more difficult for our consciousness to distinguish between reality from 
simulation of reality. Music has been playing a key role in advancing these blurred lines as its narrative can overdrive virtually any situation and we can create our own "life soundtracks", and clubs can be seen as parallel realities where these simulations can be lived out.

$M C$ - master of ceremonies or mic controller, the MC provides the vocal crowd control during dj sets, often spitting onto the beat in freestyle.

Mimesis- the act of imitation, representation, mimicry, music is mimetic in character as there is a inherent process of the passing on of knowledge through organized sound and the consumption of it through participating in the dance music event. In this context mimesis refers to the act of active socio-cultural discourse through the vibration of the crowd in regards to what is being played out.

monads- units of self organizing interactions between objects and practices eg. Production of song entitles the enactment on sound organization / sequencing, recording, repressing, playing out. Or club construction requires building structure, staff training, electricity set up.

musicking- giving and receiving information about relationship which unite the living world, and it is in fact a ritual by means of which the parcticipants not only learn about, but directly experience, their concepts of how they relate, and how they ought to related, to other human beings and to the rest of the world. Musicking is the process of participating in the music, of listening to music when cleaning your home, or staying up for hours making a song, of sharing tunes you relate to, of simply dancing in the streets with your headphones on.

Partcicipatory Action Research (PAR)- is an approach to research in communities that emphasizes participation and action. It seeks to understand the world by trying to change it, collaboratively and following reflection. PAR emphasizes collective inquiry and experimentation grounded in experience and social history.

rhythmanalysis- methods outlined by Marxist sociologist and philosopher Henri Lefebvre for analyzing the rhymths of urban spaces and the effects of those rhymths on the inhabitants of those spaces. Rhymthanalysis can be seen as to play out a key component of what ends up being the "vibe" in a club.

soundsystem- finely tuned speakers meant for providing sonic dominance in a space for dance purpose reasons. Soundsystems consist of the technologies involved in creating the speakers to the human crew engineering them and organizing their transportation and installation. 
sonics- the utilization of sound vis a vis space for the best possible acoustic experience, here referred to as sonic spaces. The occupation of a space with acoustics as a means of actualizing culture, transferring data/ information.

sonic body-seeing the human body as a whole in one sonic receptor apparatus. Our

sonic fiction- coined by Kodwo Eshun's, a concept as an advance and adequate methodological approach to sound studies. Eshun describes it in More Brilliant Than The Sun, as a machine for travelling at the speed of thought, a probe for drilling into new levels of possibility space. 'Its mission is to undermine the concepts this present has of "Health" and "Culture" and to excite mockery and hatred against these hybrid monsters of concepts.'

voguing- a highly stylized, modern house dance that evolved out of the Harmler ballroom scene in the 1980s.

\section{Table of Appendices:}

1.1 Event in 2015

May 24th 2015 [WELDON PARK 569 College St]

lyer [PHYLA]

MarcoWeibel [Darker Than Wax]

Kei-li [Darker Than Wax]

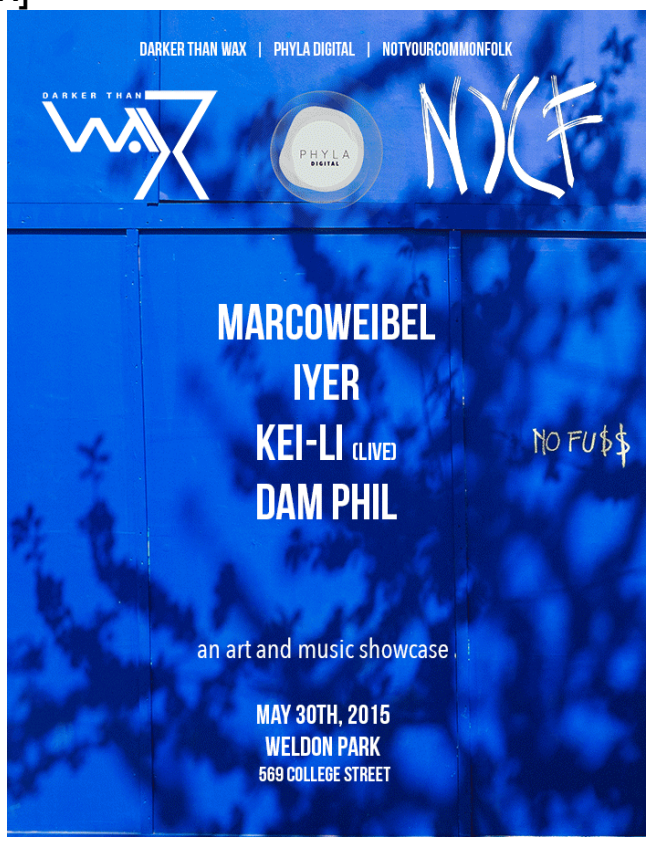




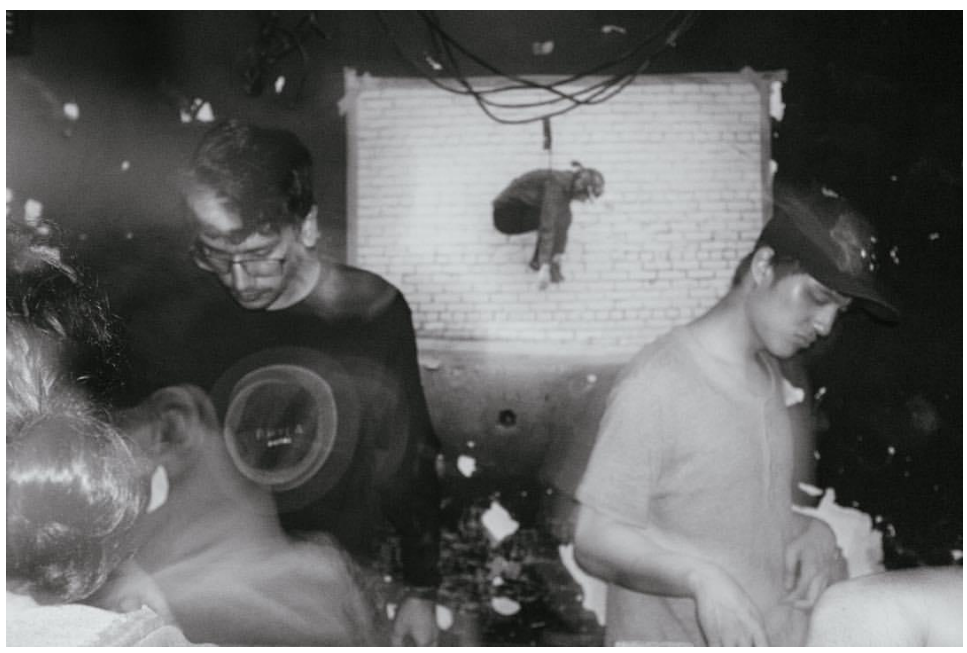

[lyer / Kei-Li @ Weldone Park, 2015]

\subsection{Event in 2016}

March 24th 2016 [The Steady 1051 Bloor St W]

KEI-LI live performance [Darker Than Wax]

Barry Nichols selector set [City Beat Records]

MARCOWEIBELI dj set [Darker Than Wax]

Cherriep Philthkids dj set / original production [Philthtrax]

Weird:L [TRP IThe Dollhouse]

Your(e) foreign bruv is an exhibition event that combines documentary with music. Photographer Philip Skoczkowski will be showcasing a teaser of his ongoing documentary "Sonic City" which revolves around notions of urban development and music culture.

The space will integrate live music performances, DJ sets, and a curated record selection, alongside large format photography and video projections as a platform for experiencing documentary as an event on its own while allowing the freedom to dance.

For twenty-five centuries, western knowledge has tried to look upon the world. It has failed to understand that the world is not for beholding. It is for hearing. It is not legible, but audible. - Jacques Attali

*The official exhibition will be held at DocNow Festival June 2nd at Rally (12 Ossington). 


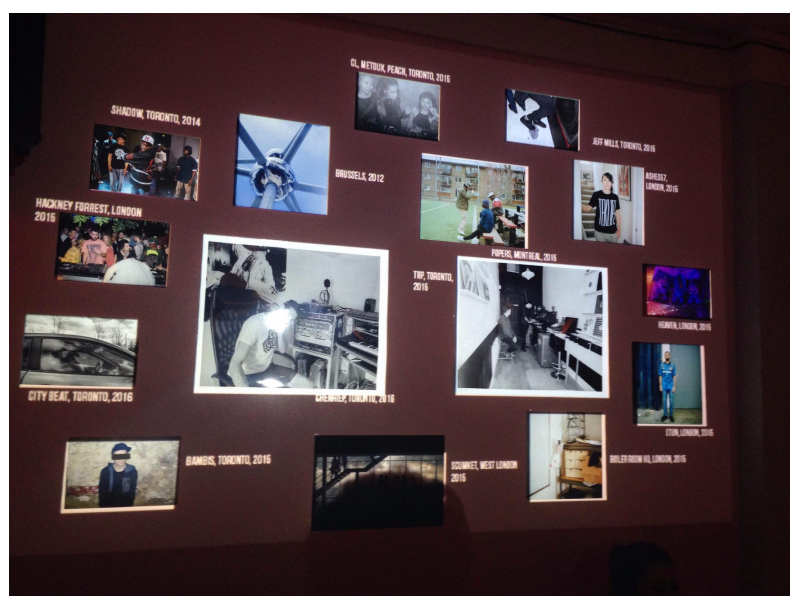

Photo prints + projections at the Steady, 2016

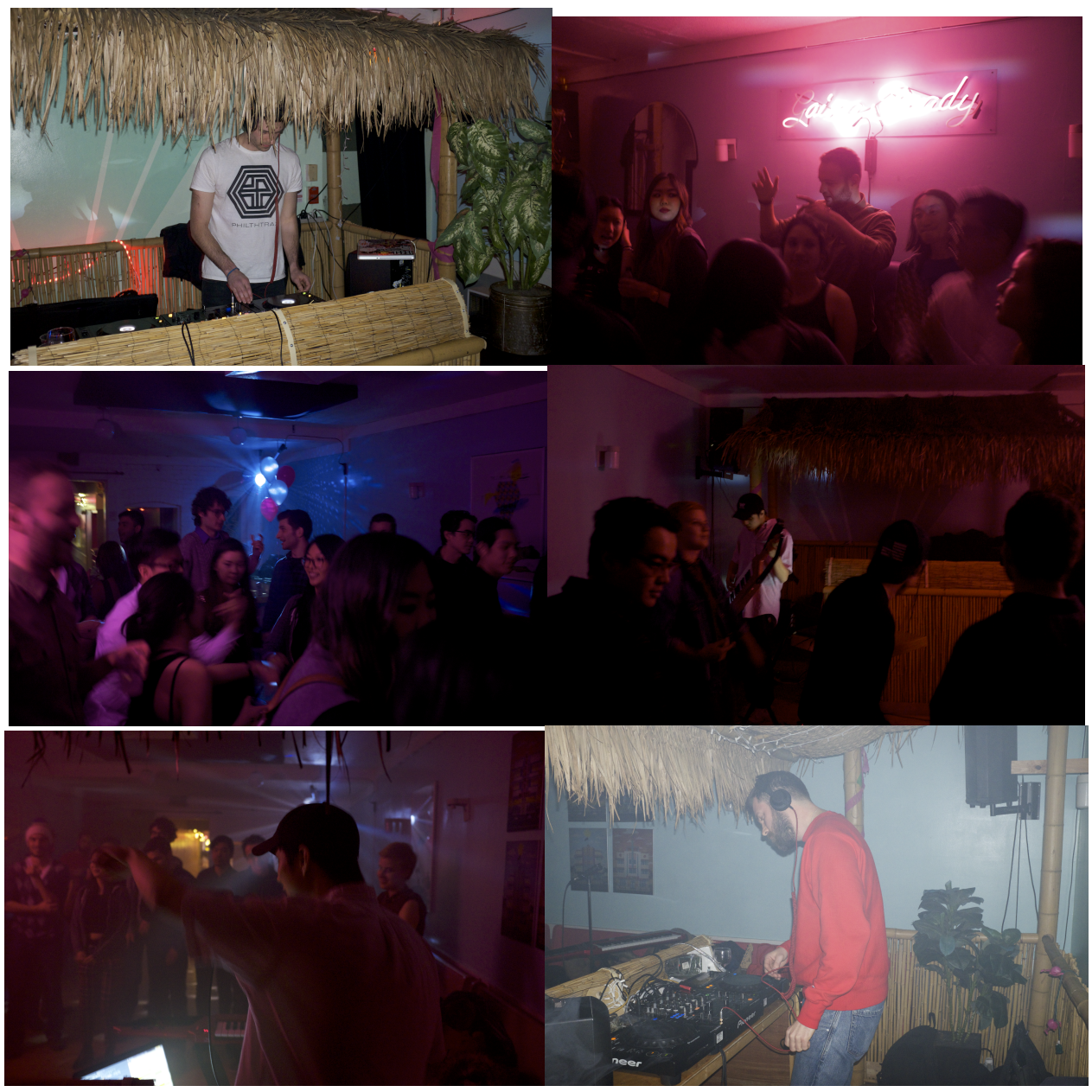

Participants / artists performances at the Steady, 2016 


\section{Works Cited:}

Andreotti, Libero. Theory of the Derive and Other Situationist Texts. Barcelona: Museu D'Art Contemporani, 1997.

Badiou, Alain, Slavoj Žižek, and Susan Spitzer. Five Lessons on Wagner. London: Verso, 2010.

Christodoulou, Chris. "Rumble in the Jungle: City, Place and Uncanny Bass." Dancecult DC 3.1 (2011): 44-63.

Deleuze, Gilles, and Félix Guattari. Anti-Oedipus: Capitalism and Schizophrenia. Minneapolis: U of Minnesota, 1983.

Deleuze, Gilles, and Seán Hand. Foucault. Minneapolis: U of Minnesota, 1988.

Deleuze, Gilles, and Félix Guattari. A Thousand Plateaus: Capitalism and Schizophrenia. Minneapolis: U of Minnesota, 1987.

Deleuze, Gilles. The Fold: Leibniz and the Baroque. London: Athlone, 1993.

Eyerman, Ron, and Andrew Jamison. Music and Social Movements: Mobilizing Traditions in the Twentieth Century. Cambridge: Cambridge UP, 1998.

Eshun, Kodwo. More Brilliant than the Sun: Adventures in Sonic Fiction. London: Quartet, 1998.

Gay, Paul Du, and Stuart Hall. Doing Cultural Studies: The Story of the Sony Walkman. London: Sage, in Association with the Open U, 1997.

Goodman, Steve. Sonic Warfare: Sound, Affect, and the Ecology of Fear. Cambridge, MA: MIT, 2010.

Hebdige, Dick. Cut ' $n$ ' Mix: Culture, Identity, and Caribbean Music. London: Methuen, 1987. 
"Kode9 Stared Into The Void And It Stared Back." The FADER. 2015.

Lefebvre, Henri. The Production of Space. Translated by Donal NicholsonSmith. Oxford: Blackwell, 1991.

"Mala at Red Bull Music Academy (Barcelona 2008)." YouTube.

Needham, Alex. "Wolfgang Tillmans to Open Music 'playback Room' in Berlin Gallery." The Guardian. The Guardian, 12 Sept. 2014.

RA.464 Paula Temple.",https://www.residentadvisor.net/podcastepisode. aspx?id=464, Resident Advisor, 2015.

Relational Soup: Philosophy, Art, and Activism | Brian Massumi \& Erin Manning | TEDxCalArts" Video at TEDxTalks." TEDxTalks. TED, 16 Sep. 2014.

Regatão, J. P. (2007). Arte Pública e os novos desafios das intervenções no espaço público, Lisboa: books on Demand, Quimera Editores, 2010.

Rojas, Eunice, and Lindsay Michie. Sounds of Resistance: The Role of Music in Multicultural Activism. Santa Barbara, Calif.: Praeger, 2013.

Rojas, Eunice. Sounds of Resistance: The Role of Music in Multicultural Activism. Santa Barbara, Calif.: Praeger, 2013.

Roy, William G. Reds, Whites, and Blues: Social Movements, Folk Music, and Race in the United States. Princeton: Princeton UP, 2010.

Small, Christopher. Musicking: The Meanings of Performing and Listening. Hanover: U of New England, 1998.

"We Want More - The Photographers' Gallery." The Photographers' Gallery. 2015. 
Roy, William G. Reds, Whites, and Blues: Social Movements, Folk Music, and Race in the United States. Princeton: Princeton UP, 2010.

Seeger, Anthony. Why Suyá Sing: A Musical Anthropology of an Amazonian People. Cambridge: Cambridge UP, 1987.

Schutz, Alfred, and Arvid Brodersen. Collected Papers. Vol. 2: Studies in Social Theory. The Hague: Martinus Nijhoff, 1976.

The Agenda, Daniel Levitin: Music and the Brain https://www.youtube.com/watch?v=RsJl6Pys880, 2010. 